\title{
Kingship in heaven in Anatolia, Syria and Greece: patterns of convergence and divergence
}

Book or Report Section

Published Version

Rutherford, I. (2018) Kingship in heaven in Anatolia, Syria and Greece: patterns of convergence and divergence. In: AudleyMiller, L. and Dignas, B. (eds.) Wandering Myths Transcultural Uses of Myth in the Ancient World. De Gruyter, pp. 3-22. ISBN 9783110416855 Available at

http://centaur.reading.ac.uk/79653/

It is advisable to refer to the publisher's version if you intend to cite from the work. See Guidance on citing.

Publisher: De Gruyter

All outputs in CentAUR are protected by Intellectual Property Rights law, including copyright law. Copyright and IPR is retained by the creators or other copyright holders. Terms and conditions for use of this material are defined in 
the End User Agreement.

www.reading.ac.uk/centaur

\section{CentAUR}

Central Archive at the University of Reading

Reading's research outputs online 
Ian Rutherford

\title{
Kingship in Heaven in Anatolia, Syria and Greece
}

\author{
Patterns of Convergence and Divergence
}

\section{Introduction}

Anyone who studies mythology in different ancient cultures will sooner or later be struck by similarities between them, and wish to understand how such similarities come about. There are three general ways of explaining similar story-patterns in different cultures:

1. as coincidence;

2. as common cultural patterns that go back very early in human pre-history; and

3. as diffusion, either long-term over several millennia (3a) or more recently (3b).

A recent proponent of position 2 is the Harvard indologist Michael Witzel who in The Origins of the World's Mythologies (2012) argues that many of the similarities between the mythologies of different cultures can be traced back to the period before the human migrations of the late Stone Age. He makes a primary distinction between features shared by cultures of Eurasia and the Americas (for which he uses the geological term "Laurasia"), and those of Africa and Australasia on the other (for which the analogous geological term is "Gondwana") which in his view diverged around 40,000 BC. For Witzel some diffusion may have taken place subsequently, but for the most part parallels are to be explained by movements of people rather than of myths.

Scholars of early Greek literature and myth have for the most part had a more limited focus. In recent decades they have been concerned particularly with two types of diffusion. One is cross-cultural diffusion from the Ancient Near East (ANE), either in the Late Bronze Age (1400-1200 BC) (LBA) or the "Orientalising Period" (eighth century BC). ${ }^{1}$ The other is linguistic and cultural diffusion associated with speakers of Indo-European languages who are believed to have spread from a common homeland, probably around the Black Sea. ${ }^{2}$ The problems posed by the two cases are slightly different, but one thing they share is that there exists widespread disagreement about how significant diffusion actually was.

To take the case of the purported diffusion from the ANE, some have argued for widespread and comparatively recent diffusion from East to West, given archaeologi-

\footnotetext{
1 Burkert 1992; West 1997.
}

2 West 2007; Watkins 1995. 
cal evidence for the movement of material culture, and textual evidence for the existence of similar patterns in different cultures. ${ }^{3}$ For others trying to pinpoint borrowing is futile given the limitations of our knowledge, and the most we can reasonably do is make comparisons. ${ }^{4}$ Witzel's work serves as a warning that diffusion is not the only way of explaining shared cultural patterns. If we are to make a convincing case for it, we have to show that it is more likely than the other hypotheses. One way of doing that might be to point to the existence of parallel names in narratives in two different traditions. Another might be to demonstrate a critical mass of parallels between narratives in two different traditions. It is also important to be able to present a persuasive narrative about how it comes about.

\section{The Succession Myth and the Near East}

The strongest case for diffusion between the Near East and Greece (and one that convinces Witzel) $)^{5}$ is that of the Divine Succession Myth as we find it in Hesiod's Theogony. Myths about the origin of the gods and their early battles are found in various cultures of the Near East, including Babylon and Ugarit, but the best parallel for Hesiod's version, as has long been known, is a Hittite narrative, known now as the "Song of Coming Forth", the surviving text of which, like those of other Hittite myths, comes from the archives of the Hittite capital at Boghaz-Köy in central Anatolia. Along with at least two other narratives it forms a sequence charting the origins of the Storm god and his early battles with monstrous challengers. These texts seem to have a background in the narrative literature and religion of the Hurrians of North Syria, with whom the Hittites had strong cultural links from the early sixteenth century BC. The Hurrian language (which was neither Indo-European not Semitic) is still imperfectly understood, and we have little independent information about their literature, although we know they had themselves absorbed the elements of the earlier cultures of Syria and Mesopotamia, and at an earlier point, when they lived further to the East, they seem to have been in contact with Indo-Iranians. The Hittite versions of the myths have sometimes been thought to be translations from Hurrian ones, but the more recent thinking is that they should be seen as loose adaptations. ${ }^{6}$

Hittite religion and poetry were in fact deeply multicultural. They had taken over central Anatolia from an earlier "Hattic" culture (another non Indo-European language) whose religion and mythology they continued to use. They also absorbed elements of another culture or group of cultures, the Luwians (Luwian was another Indo-

3 Burkert 1992; West 1997.

4 Haubold 2013.

5 Witzel 2012, 73.

6 Archi 2009; Corti and Pecchioli Daddi 2012. 
European language closely related to Hittite), who occupied parts of southern and western Anatolia. The Hittite archives contain texts translated from Hattic and Hurrian (as well as original versions), and in addition ritual texts collected from as far away as Arzawa in the west of Anatolia and Babylon. The Hittites were in diplomatic contact with Ahhiyawa (Mycenaean Greece), and one text from about 1300 BC gives us the startling information that the deities of Ahhiyawa and Lazpa (surely the island of Lesbos) were somehow present in the Hittite capital. ${ }^{7}$

The Hittite archives preserve about twenty narrative-myths, a fairly small proportion of all Hittite texts of which there are many hundreds. ${ }^{8}$ Four major classes of narrative texts are:

- narratives about the gods' conflict with the snake Illuyanka (Hoffner 1); see below $\S 6$.

- narratives relating to vanishing gods (Hoffner 2-8); these resemble Greek myths of disappearing gods, such as that of Demeter, but it is impossible to prove influence either way. ${ }^{9}$ A feature of the vanishing god narratives, as well as of the Illuyanka narratives, is that the texts supply information about the ritual context of their performance, something which tends to be absent from Greek myths and which scholarly ingenuity has long tried to supply.

- narratives relating to the theme of kingship in Heaven, adapted from Hurrian (Hoffner 14-18);

- other translations and adaptations: of the Babylonian epics of Gilgamesh and Atrahasis; ${ }^{10}$ and of an Ugaritic tale, Elkunirsa and Ashertu (Hoffner 21); an early Hittite tale, the story of the queen of Kanesh and her thirty sons and thirty daughters (Hoffner 19). The most recent addition has been a bilingual Hurrian and Hittite text called "The Song of Release", which includes narratives involving both gods and humans (Hoffner 18a). Most of these narratives involve cultural translations of one sort or another; even the vanishing god narrative and the Illuyanka narratives may be translated from the "Hattic" sphere.

7 AhT20§24.

8 I follow here the convenient enumeration in Hoffner 1998. Many of the Hittite myths now appear in Lopez-Ruiz 2013, with translations by M. Bachvarova.

9 See e.g. Burkert 1979a, 127; Bernabé 1988. One specific parallel between Demeter's disappearance in the Homeric Hymn and the Hittite myths is that a powerful goddess is involved in saving the situation: just as the goddesses Hannahanna and Kamrusepa play a part in restoring order in the Anatolian myths, so in the Homeric Hymn the abduction of Persephone by Hades is seen only by Hekate and the Sun, and it is Hekate who informs Demeter about what happened, though she claims not to know that the perpetrator was Pluto. Hekate has an even bigger role in a version of the myth attributed to the Hellenistic poet Callimachus (fr.466) who makes her a daughter of Zeus and Demeter and has her sent to the Underworld in search of Persephone. Less well known is the Argive myth-ritual of the disappearance of Dionysus, who vanished into Lake Lerna and was summoned back with trumpets: Dionysus disappearing in the water; cf. Hanhana and Kasha ritual: "he has disappeared".

10 See Haas 2006, 272-9. 
Remarkable as the Hittite narratives are, they are unlikely to have been unique in this period. A significant corpus of narratives has also been found at Ugarit (see below §5), and it seems likely that similar myths were composed, performed and archived in many parts of the Ancient Near East. For example, it has been recently argued that there was an early Levantine myth narrating the battle of the Storm-god with the Sea-deity, which had a deep influence on the Hurrian-Hittite tradition (see below). Mythical narratives seem to have wandered easily from one culture to another at this time. Their movement is particularly easy to observe within what we might call the zone of cuneiform culture (from Mesopotamia, Syria, Anatolia), but Syrian and Mesopotamian narratives even reach Egypt. ${ }^{11}$ They might well have reached the Aegean as well, or indeed moved from the Aegean to Anatolia and Syria;12 Hittite influence extended to areas where Greeks may well have encountered it, especially the West of Anatolia (known in the Late Bronze Age as "Arzawa"), but also the South-East ("Kizzuwatna") and even the Black Sea coast;"13 in the case of Syrian and other NearEastern myths the contact zone could have been the Levant or Cyprus.

Why might such myths wander? One facilitating factor is probably that different states had shared ideas about the gods, who are thus "translatable" (cf. M. S. Smith 2008). Walter Burkert in the 1980s argued for the importance of wandering ritual practitioners in cultural transfer (and cosmogonies are known to have been recited during rituals). ${ }^{14}$ Another context for wandering might be festivals, attended by travelling singers, ${ }^{15}$ and official delegates from different states. ${ }^{16} \mathrm{~A}$ further key factor could have been political ideology, which myth supports: a letter from Mari (eighteenth century BC) transmits a message to King Zimri-Lim purporting to come from the god Addu of Aleppo, saying that he had sent him the weapon with which he had battled the Sea (the first evidence for the existence of that myth), a piece of information which would obviously have been useful propaganda for Zimri-Lim. ${ }^{17}$ Similarly, in neo-Assyrian royal inscriptions the king may be presented as following in the footsteps of the victorious storm god Marduk, smiting his enemies. ${ }^{18}$

11 The Egyptian "Astarte and the Sea" (COS 1.35-36) may adapt Ugaritic "Baal and the Sea" or even the Hurrian-Hittite "Song of Ullikummi": cf. Helck 1983. The Amarna Letters (fourteenth century BC) include some mythological narratives (EA356-9).

12 Diffusion from the Aegean to Anatolia is not out of the question, and indeed it has sometimes been suggested that religious practices in Western Anatolia might reflect contemporaneous Greek practice. See e.g. Faraone 1987, 277.

13 Zalpa on the Black Sea near Samsun was an important religious centre for the Hittites: see Forlanini 1984.

14 Cf. Lopez-Ruiz 2010.

15 Travelling singers in Mari archive: Ziegler 2007.

16 Bachvarova 2016, 225-6.

17 See Durand 1993; Ayali-Darshan 2015, 40.

18 Pongratz-Leisten 2014; ead. 2015, 311; also Crouch 2013. For the tendency of rituals related to royal authority to be borrowed, see Kristiansen and Larsson 2005. Note also that the ancient Greek word "turannos" (tyrant) may go back to Luwian tarwani- : cf. Giusfredi 2009. 


\section{Hurrian-Hittite Myths: The Song of Coming Forth and the Tarpanalli-Narratives}

Three Hittite mythical narratives which chart the early history of the gods seem to belong together. ${ }^{19}$ The first is the "Song of Going Forth" ("SİR parā-kan pāwar"; see Corti 2007), previously known as "Song of Kumarbi", of which only the first tablet survives. This describes the origin of the present generation of gods, especially the Storm god (sumerogram IM), whose normal Hittite name was Tarhunt (Hurrian Tessub); he seems also to be referred to by a second Sumerian writing KA.ZAL, whose Hittite rendering might be muwatalli ("mighty") or walliura ("proud"). ${ }^{20}$ Their origin comes about via conflict between two lines of older gods: Alalu rules first, and is deposed by Anu ("sky"), who is then in turn deposed by Alalu's son Kumarbi who bites off Anu's genitals. This results in the former becoming pregnant with the latter's children, and subsequently the gods "come forth" from his body. He spits the semen of Anu onto Mt Kanzura, from where the god Tasmisu/Suwaliyat arises. Then Kumarbi visits Nippur where he gives birth to the Storm god, who emerges from the head (the "good place"), and the Tigris River, who emerges from somewhere else. Immediately after giving birth Kumarbi demands the Storm god back, so that he can eat him, but the gods give him a stone instead. ${ }^{21}$ The tablet ends with the young Storm god exalting in his glory and the earth on the point of giving birth to twins. Only the first tablet survives, and it is unclear how many tablets might have followed.

Significant new information has now become available in another text whose modern title is "Ea and the Beast". In this, the coming of the Storm god is narrated in the form of a prophecy delivered by the "Beast" in conversation with the god Ea. ${ }^{22}$ If the reconstruction is right, the long fragment consist of two sections:

1. (col.ii): the triumph of the Storm god, who will drive down his enemies to the underworld, and keep them defeated with strings. He will judge the gods. The earth will produce a "tarpalli" (presumably the same as a tarpanalli: see below), described apparently as "the snake (musilluyanka) of the mountains, rivers, sea".

2. (col.iii): apparently a flashback: the creation of the earth and the installation of someone (presumably the Storm god) as king by the fate-deities; then apparently the theme of Kumarbi's giving birth to the various gods, though a different set from that in the Song of Coming Forth.

19 Full survey: Haas 2006, 130-75; Archi 2009; see also van Dongen 2012; Ayali-Darshan 2015.

20 See Corti and Pecchioli Daddi 2012.

21 §13: the Storm-god wonders how to get out of Kumarbi's body, and chooses the "good places", which is apparently the skull. "He split him like a stone. He left him, namely Kumarbi. The divine Muwatalli(?), the valiant king, came up out of his skull”; then in \$14 Kumarbi demands the child back, so that he can eat him, and the gods give him a stone instead. See Beckman 2011.

22 Archi 2002; Rutherford 2011. 
Two other narratives provide a sequel to the Song of Coming Forth. The Song of Hedammu (Hoffner 17), a very fragmentary text, narrates the story of the sea monster Hedammu, child of Kumarbi and a daughter of the Sea god, who is described as a "tarpanalli" ("substitute" or "challenger") against the Storm gods. It seems that the gods deal with the threat by having the goddess Sauska/Ishtar seduce it, a motif that Nora Ayali-Darshan (2015) has recently argued is borrowed from an earlier narrative of the Storm god's conflict with the Sea, which originated somewhere in the Levant. The Song of Ullikummi (Hoffner 18), the longest of the extant texts in three cuneiform tablets, narrates a further conflict between the gods and a blind and deaf stone giant, Ullikummi son of Kumarbi. Ullikummi, whose name means "Destroy Kummiya" (the home of Tessub), is also described as a tarpanalli. Kumarbi has the infant Ullikummi planted on the shoulder of Ubelluri, a sort of Atlas figure who supports the heaven and earth $(\S 16, \S 61)$. The Sun god sees him growing in the sea (§22-3: "it was standing like a shaft with the sea coming up to its knees") and reports to the gods, who go to Mt Hazzi (Mons Kasion) to observe. They initially try having Sauska seduce it again, but a great wave of the sea points out that this is futile (§36) (This motif clearly presupposes the Song of Hedammu). Then the Storm god and the gods drive their chariots against him but they fail. Hebat, watching the battle, wonders whether her husband is dead (§44-5). Eventually, Tasmisu/Suwaliya advises Tessub to visit Ea in Apzuwa (the Mesopotamian Apsu, the subterranean waters). Ea in turn visits Ubelluri and persuades the Primeval gods to release the copper cutting tool that was originally used to separate earth and sky (a detail heard about only here) in order to detach Ullikummi from the ground (\$63). This is done. Ea is apparently shocked at seeing the dead in the Underworld (§65). When the text breaks off, we may be in the middle of the final battle.

According to Ayali-Darshan, the Song of Ullikummi too incorporates material from a Syrian tradition about the battle with the Sea. One borrowed feature would be the role of Mt Hazzi, also found in the Ugaritic narrative about Yamm (see below). ${ }^{23}$ The abortive seduction of the Sea also seems to come from that tradition. If the original setting of Ullikummi is rocky central Anatolia, ${ }^{24}$ perhaps we can see the Ullikummi story as an early wandering myth, Mediterraneanized by contact with Syria, just as Ullikummi himself is born inland and transplanted to the shoulder of Ubelluri, from where he grows up through the Mediterranean Sea.

The Luwian term "tarpanalli" is applied to both Hedammu and Ullikummi and the snake in Ea and the Beast is called a tarpalli, presumably the same thing. In ritual contexts "tarpalli" means a substitute, referring to a sacrifice made in place of someone else, e.g. the king, a common Near-Eastern practice. Possibly the idea behind it is that the monster replaces the Storm god temporarily as ruler of the universe but is

23 Ayali-Darshan 2015, 46 n. 77.

24 Haas 2006, 157. 
fated (cf. Ullikummi §48) to be destroyed/sacrificed in the same way that a king in the Ancient Near East was replaced temporarily by a human substitute if there was reason to think that his life was in danger. ${ }^{25}$

Other narratives may belong in the same sequence: ${ }^{26}$

- the Song of LAMMA (Hoffner 15), also very fragmentary, is named after the deity designated by the Sumerian sign LAMMA, which implies that he is one of a broad class of Anatolian deities known as the "tutelary" deities. Volkert Haas suggested that it was Kurunta, a Luwian deity represented as a stag (the name could in fact mean "horned"). ${ }^{27}$ At the start of the narrative he had for some reason defeated Tessub, and is allowed by Kumarbi and Ea to assume leadership of the kosmos. His rule ushers in a sort of Golden Age, a consequence of which is that no one feeds the gods. Kubaba (his spouse?) urges him to go talk to the Primeval gods. He refuses, so they depose him.

- The Song of Silver narrated the story of Silver, another son of Kumarbi, who seems to have assumed the rule of heaven for a brief while. ${ }^{28}$

- Another fragment has recently been published featuring a period of rule by another primeval deity, Eltarra. ${ }^{29}$

- There was probably also a narrative narrating a conflict between the Storm god and the Sea, along the lines of the Ugaritic narrative of Baal and Yamm, and probably originating in a much earlier Syrian or Levantine version. ${ }^{30}$

Traces of some of these narratives survive in Hurrian as well, ${ }^{31}$ though the Hurrian stage was not the original one. Hurrian religion underwent early influence from Mesopotamia and Syria (see Archi 2013), and the narratives will have been influenced in the same way. Most of the details are beyond our understanding at present, but one case where Mesopotamian influence shows clearly is the figure of Ea, Mesopotamian god of wisdom, who seems to play a crucial part in the action of

25 See Corti and Pecchioli Daddi 2012, 617. On substitute rituals, see Huber 2004.

26 Bachvarova 2016, 27 is sceptical about whether the Song of LAMMA and the Song of Silver belong in this sequence.

27 Haas 2003. Archi 2009, 218 suggested that Kurunta is the Luwian form of LAMMA, corresponding to Karhuha, the deity of Carchemish, where he believes that poem originated. Haas suggested that the end of the myth of LAMMA where the god is killed can thus be seen as a sort of precursor to the Greek myth of Actaeon, the man who is transformed into a stag and torn apart by hunting dogs.

28 Recently compared to the Greek story of Phaethon by James and van der Sluijs 2012.

29 Polvani 2008; Dijkstra 2011, 70-72.

30 See Rutherford 2001 and Dijkstra 2011, who explores links with the Hedammu myth and the Ugaritic material; Ayali-Darshan 2015 studies the evolution of the Sea-myth.

31 Edited in Salvini and Wegner 2004. 
the some of narratives, initially supporting the rebels, but later on working with the Storm god. ${ }^{32}$

\section{Ugaritic and Phoenician Myths}

An already complex situation is complicated still further by the evidence for a related narrative tradition from Syria and the Levant. The best evidence comes from Ugarit (Late Bronze Age), but we have indirect evidence for Mari on the Euphrates (Middle Bronze Age) and also Phoenicia (first millennium BC). ${ }^{33}$

Ugarit was an important kingdom in the Late Bronze Age, destroyed around $1180 \mathrm{BC}$ at the same time the Hittite kingdom itself vanished from the record. Excavations there in the 1930s yielded a corpus of previously unknown narrative poems, including one group concerned with Baal of Mt Șapanu (Mt Kasion, just North of Ugarit). Surviving narratives deal with Baal's combat against his adversaries Yamm (the Sea) and Mot (Death). The combat with Yamm is a sort of proem, followed by Baal's building his palace on Mt Sapanu; the combat with Mot is more complex, divided into two sections, the first of which concludes with the temporary death of Baal. Although no Ugaritic divine succession myth has been found, there may be a trace of Hurrian-Hittite myth in the fact that Baal has two different fathers, Dagan (usually) and $\mathrm{El}$ (see below).

The narrative of the battle between Baal and Yamm is a general resemblance of the Egyptian Astarte narrative and the Hittite-Hurrian Song of the Sea and one specific point they have in common is that all three have an episode where the Sea demands tribute from the gods. It seems likely that behind all of them is an older narrative about the Storm god and the Sea which originated in the Levant. ${ }^{34}$

No narratives in Phoenician survive at all. However, a Greek writer from the early Imperial period, Philo of Byblos, claimed to have access to an otherwise lost work by the Phoenician author Sanchuniathon. ${ }^{35}$ Sanchuniathon's Theogony as reported by Philo is long and complex, and it includes Egyptian elements such as the god Thoth (not necessarily a sign of inauthenticity, since there actually was a lot of Egyptian influence in the Levant in the Late Bronze Age). One subnarrative in it was devoted to a sequence of three or four generations of gods:

32 See Hoffner 1998, 41-2. Ea's position in Hesiod's Theogony has something in common with that of Gaia, also a primordial chthonic figure, whose wise advice is critical to Zeus' success, although she acts against Zeus when she gives birth to Typhon: Strauss Clay 2003, 26-7. Another case of Syrian influence may be the myth of the Storm god and the Sea, for which see below.

33 For Mari see above. For even earlier evidence from Ebla (third millennium BC) see Bachvarova 2016, 257.

34 Ayali-Darshan 2015; Dijkstra 2011.

35 See the edition of Baumgarten 1981. 
Generation 1: Elioun (Most High) and Berouth (in Byblos).

Generation 2: Ouranos (Sky), whose original name was "terrestrial autochthon”, and Earth.

Generation 3: Elos/Kronos, Baitylos, Dagon/grain and Atlas. These are the Titans. Generation 4? Demarous.

Ouranos is deposed by Elos/Kronos because he maltreats Earth. Ouranos has a concubine, who is pregnant with Demarous (apparently Zeus, also called Adados, i.e. Hadad, the god of Aleppo). He gives her to Dagon as wife, so Dagon becomes the stepfather of Demarous. At a later point Kronos castrates Ouranos.

It is possible that this is a piece of Hellenistic or Roman local history, a pastiche from earlier mythological elements including some from Hesiod (the inclusion of the castration of Ouranos towards the end looks suspicious), constructed to give Phoenicia a privileged place in the origin of the kosmos. ${ }^{36} \mathrm{~A}$ similar local theogony involving Titans is known from Adana in Cilicia, possibly going back to the philosopher Athenodorus of Cana (first century AD). ${ }^{37}$ However, in recent decades scholars have begun to appreciate that Greek historiography about the Ancient Near East (such as Berossos' Babyloniaca) is far from being completely unreliable, and often contains authentic material. ${ }^{38}$

One episode in Philo that may well point back to the Bronze Age is Ouranos' giving his concubine, who is pregnant with Demarous, to Dagon so that Dagon brings him up; Dagon clearly corresponds to Dagan, an ancient Semitic deity, attested already in the third millennium BC, often identified with Kumarbi in Hittite texts. ${ }^{39}$ Thus this episode could be construed as a faint echo or rationalisation of Kumarbi's acting as parent of Anu's child in the Song of Coming Forth, except without the sexual violence. ${ }^{40}$ Kumarbi's role seems to have been divided in two: the supplanter of Anu (Elus/Kronos) and the surrogate father of his child (Dagon).

There may be intimations of this in Ugaritic texts, in which both $\mathrm{El}$ and Dagon are said to be the father of Baal; as we saw, that may reflect the dual paternity of the warrior god in the Hurrian tradition. ${ }^{41}$ Some deity-lists from Late Bronze Age Ugarit preserve a similar sequence of gods: Ilu (El), Dagan and Baal Șapanu (i. e. Baal of Mt Șapanu). ${ }^{42}$ It

36 Baumgarten 1981, 6 and 261-68 takes this view; for bibliography see now Metcalf 2015, 179.

37 The entry for Adana in the lexicon of Stephanus of Byzantium states that Adana was founded by

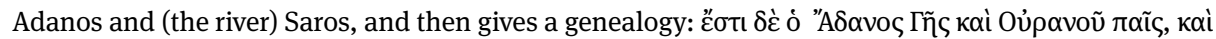

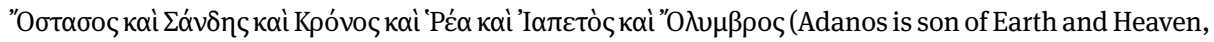
along with Ostasos, Sandes, Kronos, Rhea, Iapetos and Olumbros). Three of the children (Kronos, Rhea, Iapetos) are Hesiodic Titans. On this see Rutherford 2017, 89-90.

38 See Dillery 2015.

39 Feliu 2003, 106.

40 Lopez-Ruiz 2010, 99-100.

41 See the important article of Ayali-Darshan 2013 on this.

42 Lopez-Ruiz 2010, 102; Pardee 2002, 30 etc. 
is thus possible that there is some degree of continuity from a narrative parallel to the Song of Coming Forth, but we cannot be sure that there was an act of violent copulation between two male divinities in the Ugaritic or proto-Phoenician myths: it is possible that what comes through the Semitic tradition is simply the bipaternity of the Storm god, for which Sanchuniathon provides an explanation consistent with the grammar of genealogy.

\section{Hesiod's Theogony and the Song of Coming Forth}

On the Greek side, the standard source for the creation myth is the Theogony, composed probably in the late eighth century BC by Hesiod of Ascra in Boeotia whose family came from Cumae in W. Anatolia. The Theogony charts the history of the universe from the beginnings to the present cosmic. There are two phases:

1. The generations of the gods, with greatest emphasis on the most recent four generations and the transitions between them. The generations are first, that of Ouranos (Sky) and Ge (Earth); second, Kronos and the Titans; third, Zeus and his siblings; and fourth, Zeus' children. Ouranos suppresses his children, the twelve Titans, but Kronos overthrows him by castrating him when he comes to penetrate Ge. The blood of Ouranos falls on Ge and engenders the Erinyes, the Giants and the Meliai-Nymphs, and the genitals fall in the sea, from where Aphrodite is born. Kronos tries to prevent his own overthrow by swallowing his children, but Zeus tricks him into swallowing a stone instead, and he disgorges the rest, which lead to the current regime of gods. Zeus is warned by Ouranos and Gaia that any son he has by the Titaness Metis will be more powerful than himself. So he swallows Metis, and the goddess Athena is born from his head.

2. Challengers to the cosmic order: first, the Titans, whom the gods defeat with the help of the Hundred-Handers; and then Typhon (820-68).

A third theme in the poem is the relationship of gods to men, and here we have the episode of Prometheus, son of the Titan Iapetos, who tricked Zeus in the first sacrifice, and when Zeus withheld fire from men, stole it, in retaliation for which the gods created the first woman, Pandora, a disaster for men (the position of Pandora in the story seems roughly parallel to that of Eve in Genesis). ${ }^{43}$

Hesiod's other surviving poem, Works and Days, contains no cosmogonic material, though it does present an anthropogenic myth, the "myth of the races", the golden race, the silver race, the bronze race, the race of heroes and the present iron race. The period in which the golden race lived was a golden age, presided over by Kronos,

43 See the treatment of the myth by Vernant 1980. 
where the crops grew of their own accord. Works and Days has a second account of the creation of Pandora, but neither poem gives an account of the origin of man. ${ }^{44}$

Over the last eighty years many similarities have been observed between Hesiod's Theogony and the Hittite narratives, almost all of them concerning the Song of Coming Forth. ${ }^{45}$ These include:

- there are three stages (generations in the Greek but not in the Hittite), from rule by Sky to the present stage, with something else in between;

- the transition from stage 1 to stage 2 comes about via the emasculation of Sky;

- $\quad$ the gods of stage 3 grow from inside a member of stage 2;

- a god swallows a stone thinking that it is another god;

- a god gives birth to another god through his head (the Storm god from the head of Kumarbi; Athena from the head of Zeus);

- a god is born from the semen of another god (Kumarbi spits Anu's semen onto Mt Kanzura, from where the god Tasmisu/Suwaliyat was born; Ouranos' semen lands in the sea and Aphrodite is born). ${ }^{46}$

There are also some differences. In the Song of Coming Forth there are originally two families, not one, and three stages with two generations, not three: Kronos emasculates his father, but Kumarbi emasculates the god who deposed his father. The HittiteHurrian Storm god is the son of the Sky, whereas Zeus is his grandson. Kumarbi's role is much more transgressive than that of Kronos, since Kumarbi inadvertently becomes the mother of Sky's children. In Hesiod it can be argued that the castration of Ouranos is the moment of final separation between Sky and Earth, allowing the Titans to come forth, but in the Hittite tradition, as we learn from the Song of Ullikummi, the separation of Earth and Sky was carried out with the copper cutting tool, apparently a separate event from the battle between Kumarbi and Anu, and long before it.

The question also arises whether there are parallels or differences between Hesiod's succession myth and Ugaritic or Phoenician myths. This is impossible to answer, since so little survives. ${ }^{47}$

44 On that see Bremmer 2008, 19.

45 First in Forrer 1936; followed by Barnett 1946, and Lesky 1950.

46 On the role of aetiology in this context see Metcalf 2015, 179-82.

47 Lopez-Ruiz 2010, 115-29 makes a good case for a parallels between the depiction of Baal's father El in Ugaritic narratives and Greek ideas about Kronos (equated with Elos by Sanchuniathon). However, the Ugaritic tradition seems to be different, both because Baal has two fathers, each of whom seems to correspond to Kumarbi, and because there is no trace of the violent succession narrative. On this, see Dijkstra 2016, 127; Dijkstra also has much to say about El, his chthonic associations and his resemblance to Kronos. 


\section{Typhon and the East}

How do the rest of the Hittite myths of this sequence compare with Hesiod and Greek mythology? Hedammu and Ullikummi resemble Typhon only in a very general way. Typhon is not the son of Kronos in Hesiod (although he has that role in one anonymous source). ${ }^{48}$ Typhon differs from Hedammu because he is not a sea-monster and he differs from Ullikummi both in his form, and in the way he is defeated. Other Greek monsters are a better match for Ullikummi, such as the giant Aloeadae Otus and Ephialtes who attempted to storm heaven by piling one mountain on top of another. ${ }^{49}$ The scene where the Sun deity catches sight of Ullikummi rising from the waves perhaps has a resonance in a completely different Greek text, Pindar's Victory Ode for Diagoras of Rhodes (lines 62-3), where Helios claims the island of Rhodes for himself after he sees it rising from the sea.

Slightly better parallels are now provided by Ea and the Beast, in which, as we saw, Tessub seems to have driven his enemies down to the earth and bound them (like Hesiod's Titans), ${ }^{50}$ and then to have fought a snake, Illuyanka or an illuyanka (like Typhon?). ${ }^{51}$ The enemies driven down to the underworld seem to correspond to the Titans in Hesiod, and it is quite possible that these events were also told in the lost continuation of the Song of Coming Forth. ${ }^{52}$

The Song of LAMMA does not seem to resemble anything in Hesiod either, though it is worth observing that LAMMA's revolution against the divine order has one parallel with Greek literature: the idea that the gods are deprived of sacrifice occurs in Aristophanes' comedies, for example in his Birds, where the gods are starved out of heaven because their access to the savour of the cooking sacrificial meat is cut off. ${ }^{53}$ Perhaps some common myth-ritual pattern underlies this.

The snake called Illuyanka, who features in Ea and the Beast, is also the focus for the Illuyanka-narratives, from the Hittite homeland (probably pre-Hittite), apparently associated with the Purulli-festival at Nerik, an important state-festival. There are two versions:

48 A scholion on Homer reports that Typhon's father was Kronos (i.e Kumarbi), the product of one of two eggs, buried in Cilicia ( $\Sigma$ on Il. B.783; ed. Dindorf III 148-9).

49 See Burkert 1979b for another parallel with Greek mythology.

50 Cf. Ea and the Beast ii.10-11; also in the Purifying a House Ritual (CoS 1.171§33). "He takes three birds and offers two of them to the Anunnaki deities, but the other bird he offers to the Pit and he says as follows: 'For you, Oh primordial deities, cattle and sheep will not be forthcoming. When the Storm god drove you down to the Dark Underworld he established for you this offering."'

51 Ea and the Beast ii.27.

52 Notice that for Solmsen 1989 the Hesiodic themes of kingship in heaven and driving the Titans down to the underworld came from distinct Near-Eastern traditions; we now know they were both present in the Hittite version.

53 Aristoph. Av.188-93, 1514 etc.; cf. id. Plut.1113-20. 
Version 1: The Storm god is defeated by Illuyanka, who is in turn tricked by the goddess Inara, the Storm god's daughter, and the mortal Hupasiya, who feast him and get him drunk. Hupasiya ties him up and the Storm god kills him.

Version 2: The Storm god is defeated by Illuyanka, who takes the heart and eyes of the Storm god; meanwhile, the Storm god has a son by the daughter of a poor man; the son marries Illuyanka's daughter and demands the heart and eyes as the brideprice. The Storm god recovers, does battle with Illuyanka, but kills his son in the process.

Parallels have been observed between these and the Greek myth of Typhon, though not the Hesiodic version. Further details about him are preserved by later sources:

1. The mythographer Apollodorus (first century AD?) (1.6.3) says that Zeus chased Typhon as far as Mt Kasion (Mt Hazzi), attacking him with thunderbolts and a sickle (harpe). But Typhon stole his sinews ("neura"), imprisoned Zeus in the Corycian Cave in Cilicia, along with the sinews, which were hidden in a bearskin, guarded by the she-dragon Delphyne. But Hermes and Aigipan (apparently a form of Pan) restored them to Zeus, who chased him to Thrace and finally imprisoned him under Mt Etna.

2. The poet Oppian (second century AD) in his Halieutica (3.15-28) situates the conflict at Corycus in Cilicia, where Pan saved Zeus by luring Typhon from his undersea lair with a banquet of fish. Pan is said to be the son of Hermes.

3. The poet Nonnus (fourth century AD) (Dion.1.481ff.) has an elaborate account in which Typhon steals first Zeus' thunderbolts, and then, after attacking heaven, steals his sinews as well. The mortal Cadmus, with the help of Pan, disguises himself as a shepherd and challenges Typhon to a musical competition. He retrieves the sinews by asking Typhon for them so that he can string his lyre. Meanwhile, Zeus steals back his thunderbolts and after some violent resistance Typhon is defeated.

At least some of this may be much earlier than the Hellenistic period. Oppian was a Cilician, and his version could be a local Corycian version rooted in Luwian tradition; ${ }^{54}$ but Typhon is already associated with Cilicia in the fifth century BC, so it is possible some Corycian version was already known to Greeks at that time. ${ }^{55}$ Parts of \#1 may also go back to some early source, perhaps the Titanomachia, ${ }^{56}$ and it is conceivable that this version actually predates Hesiod (as Joseph Fontenrose thought). ${ }^{57}$ A work

54 See Houwink ten Cate 1961, 206-15; Lytle 2011, 371-3; Hicks 1891, 241.

55 Pind. Pyth. 1.17 and Ps. Aesch. PV 353. Homer and Hesiod both associate Typhon with a people or place called Arimoi, the location of which is unknown: but see Bonnet 1987, 133-4; Lane Fox 2008, 280-301.

56 Argued for by Tsagalis 2013 and Ogden 2013, 74, but see D’Alessio 2015.

57 Fontenrose 1959, 70-6. 
attributed to the Cretan seer Epimenides (possibly fourth century BC) may have contained the detail that Typhon succeeded in storming Zeus' palace because Zeus was asleep, ${ }^{58}$ and Robert Fowler has suggested that this version may also have referred to Mt Kasion. ${ }^{59}$

Versions 1 and 2 have parallels with the Illuyanka stories. In 1930 Walter Porzig pointed out that the detail reported by Apollodorus that Typhon steals Zeus' sinews ("neura") roughly resembles Illuyanka 2. And in 1962 Houwink ten Cate observed that Oppian's version in which the deception of Typhon happens at a feast has a parallel in Illuyanka 1 (208-9). Illuyanka 1 also anticipates Nonnus' version in giving a critical role to a mortal. Perhaps Illuyanka 1 survived at Corycus where Luwian traditions were particularly well preserved down to the Greco-Roman period. ${ }^{60}$

These parallels are not particularly precise (which matters, since dragon-slaying myths are common in all cultures). But if there is anything in them, the prima facie consequence is that early Greek cosmogony draws on two different strands of Anatolian mythology: Hesiod's divine succession myth on the Hittite-Hurrian Song of Coming Forth and the non-Hesiodic Typhon myth on Hattic-Hittite mythology as we find it in texts relating to Nerik (Hesiod's version of the Typhon myth does not look particularly Anatolian at all). We should be aware, however, that the impression of distinct traditions of Hittite mythology may be an illusion generated by the limited evidence that happens to survive. In fact, Anatolian mythology may have been a lot more mixed up than that (as the religious system itself was), and it is perfectly possible that what we call the Hurrian-Hittite tradition also had Illuyanka-narratives of this sort, just as the Hattic-Hittite tradition might have had a myth of divine succession.

Typhon has also been linked to the Levant. The Hesiodic Typhon has a vague resemblance to Yamm, because he seems to be associated with the sea, although, as Peter Haider shows, there are also resemblances to a range of Ancient Near-Eastern mythical monsters, including the Sumerian Anzu-bird. ${ }^{61}$ It has even been suggested that the name "Typhon" points eastwards, if it is connected to Mt Sapanu, the Semitic name for Mt Hazzi. ${ }^{62}$ This was the seat of Baal who was known as Baal Sapanu, a deity whose cult was widely disseminated in the Mediterranean (often under the Greek

58 FGrHist. 457F8, VS3B8; Epimendes 10 in Fowler 2000-13, 1, 97. Contrast Ps. Aesch. 360 who says that Zeus struck Typhon with an "unsleeping missile” (Ogden 2013, 74), perhaps an indication that this detail is earlier.

59 See previous note.

60 Lytle 2011. Houwink ten Cate 1961, 128-9 has argued, on the basis of nomenclature, that the deity Runtas (supposed to be a later version of Kurunta, a Luwian tutelary deity) must have still been worshipped in the area, and that he should be identified with Hermes who assists Zeus in Oppian's version of the Typhon Myth (see now Lytle 2011, 370-9).

61 Haider 2005, 321; there is a resemblance to the seven headed Sea-deity Litan whom Baal is said to have fought in the Baal Cycle: see Parker 1997, 141-3.

62 Bonnet 1987, 133; Gruppe 1889, 487, cites even earlier literature. 
name Zeus Kasios). ${ }^{63}$ From the point of view of phonetics that seems fine (the Greek tau may correspond to Phoenician Șade as in the case of the Greek Turos and the Phoenician Șor), but on the semantic level we need an explanation for how the seat of the Storm god came to be reinterpreted as the name of his adversary. ${ }^{64}$ It suggests an adversarial form of borrowing, in which a foreign myth was flipped over so that its hero is reinterpreted as its anti-hero. ${ }^{65}$

\section{Conclusions}

The Hesiodic succession-myth and the Song of Coming Forth share so many motifs (a "critical mass", as I called it in the introduction) that it seems likely they are connected, at least indirectly. In theory, influence could have happened in either direction; Greek influence on Near-Eastern texts is not out of the question even at an early date (did early Greek myths wander to Hattusa along with the deities of Ahhiyawa and Lazpa perhaps?). ${ }^{66}$ Nevertheless, the probability is very much in favour of the borrowing being from East to West.

This was only a late stage in a much longer process, however: just like the generations of gods, the myths had even earlier stages. As well as moving from the Hurrians to the Hittites, they had been influenced at some point by Mesopotamian traditions. No doubt the real situation was even more complex. ${ }^{67}$

The case for a borrowing of the Typhon myth is less straightforward: different clues point toward the Hittite Illuyanka poems, local traditions at Corycus, and the Weather god of Mt Hazzi/Sapanu/Kasion, and the hypothetical proto-Syrian myth of the Storm god and the Sea is likely to have been a factor as well.

The northeast corner of the Mediterranean had long been a region of intense cultural interaction. In the LBA there was trade between Ugarit and Hittite-controlled Ura, ${ }^{68}$ which must have been somewhere in Rough Cilicia, and the religion of Kizzuwatna in this period seems to have been a mixture of Luwian, Hurrian and Syrian

63 See Koch 1993; Fauth 1990.

64 See Lopez-Ruiz 2010, 112. Gruppe 1889 had thought that Hebrew zephon could mean "North wind". 65 One possibility is that this could have happened in Egypt: a secondary cult of Baal Șapanu is known to have existed in northeast Egypt near Pelusium, presumably introduced by immigrants in the mid second millennium BC: see Fauth 1990, 110-6. There he was identified with the Egyptian god Seth, who also defended the cosmos against a monstrous threat, in this case the snake Apophis, but came increasingly to be seen as the destructive adversary of Osiris and Horus: see Velde 1967, 138-51.

66 For possible Hesiodic influence on the Hebrew Bible see Louden 2013 (on the relation between Iapetos and Japeth).

67 Egyptian influence may have been underestimated: cf. on possible Egyptian influence Faraone and Teeter 2004. On possible Indo-European influence see Rutherford 2009, 9-14, esp. 13.

68 Haider 1995. 
elements. Similarly, in the Iron Age, the Phoenicians are known to have been active in Cilicia. In the same way, Hurrian-Hittite, Hittite and Syrian narrative traditions were probably already somewhat mixed up in the LBA, and that probably continued in the immediately following. It thus becomes impossible to say for sure whether transmission is via a Luwian/Anatolian route or Syrian/Levantine one.

At any rate, it seems possible that the myths reached Greece from there, crossing to Cyprus and Crete (both important places in Hesiod), or along the southern coast of Turkey, and round to Ionia. This could have happened in the LBA or in the early decades of the first millennium. If we assume transmission in the first millennium, it might have come about in the area of Corycus, where indigenous Luwian culture still flourished in the first millennium BC. (Thus, the god Sandas was associated particularly with Tarsos, who continues the LBA Luwian deity Santas). ${ }^{69}$ Greek colonisation in Cilicia starts in the eighth century BC. ${ }^{70}$ Alternative, Hittite ideas might have been preserved in Neo-Hittite kingdoms of North Syria, such as the recently discovered kingdom of Taita in Palistin near Aleppo, perhaps in the context of cultic activities at Mt Kasion. ${ }^{71}$

However, it may be a mistake to infer from the various pieces of evidence that link the myths to Cilicia and the Levant that the Greeks must have encountered them in the vicinity. There is another possibility, namely that they reached Greece via Western Anatolia. Connectivity was very good across Anatolia in the Hittite period, and indeed it had been since the early second millennium BC, when we know of trading links between Assur and central-west Anatolia and beyond. ${ }^{72}$ In the LBA the Storm god was worshipped throughout Anatolia, and the canonical myths about his rise to power and early conflicts could have been widely known and widely performed. In the mid second millennium BC there were powerful states in the West, especially Arzawa, which we can infer from theophoric royal names had a Storm god. ${ }^{73}$ Mycenaean Greeks were already operating in Western Anatolia in the LBA, and it seems perfectly possible that they encountered these myths then. A similar argument could be made for the first millennium BC, when Lydia might have played a key role in transmission, either because it inherited religious traditions from the previous millennium or because it had close contacts with the kingdoms to the East. ${ }^{74}$ As well as its association with

69 Rutherford 2017.

70 Some think the existence of a polity called Hiyawa in east Cilicia, now attested for the tenth century BC, suggests an even earlier Greek presence: see Jasink and Marino 2007 and now Dinçol et al. 2015.

71 See Strauss Clay and Gilan 2014; for Mt Kasion see Rutherford 2001.

72 See Barjamovic 2011. For religious links: Cammarosano 2015.

73 Tarhundaradu of Arzawa (fourteenth century BC), Tarhunaradu of the Seha-River Land (thirteenth century BC). Notice that Mason 2008 has suggested that the capital of Lesbos, Mytilene, might owe its name to the Hittite adjective muwatalla ("mighty"), which was the name of a Hittite king of the early thirteenth century BC and also perhaps one of the names of the Storm-god (see above).

74 For Lydia as a route for the passage of Anatolian myth to the Greeks see Bremmer 2008, 87. The recent argument of Arnaud 2015 for a cuneiform Lydian theogony does not seem convincing to me. 
Corycus, the Typhon-myth served as an aetiology for the Katakekaumene area of Lydia, and this could well go back to an indigenous Anatolian myth about the Storm god and a snake. ${ }^{75}$ Since myths of this sort could have existed all over Anatolia for a very long period, it would be sensible to keep an open mind about where and when they passed to the Greeks.

\section{Bibliography}

Archi, A. Ea and the Beast. A Song Related to the Kumarpi Cycle, in: Silva Anatolica. Anatolian Studies Presented to Maciej Popko on the Occasion of his 65th Birthday, edited by P. Taracha (Warsaw, 2002), 1-10.

Archi, A. Orality, Direct Speech and the Kumarbi Cycle. Altorientalische Forschungen 36:2 (2009), 209-229.

Archi, A. The West Hurrian Pantheon and Its Background, in: Beyond Hatti: a Tribute to Gary Beckman, edited by B. J. Collins and P. Michalowski (Atlanta, 2013), 1-21.

Arnaud, D. Une cosmologie lydienne en langue babylonienne: BM 74329. Aula Orientalis 33 (2015), 5-20.

Ayali-Darshan, N. Baal, Son of Dagan: in search of Baal's double paternity. Journal of the American Oriental Society 133:4 (2013), 651-657.

Ayali-Darshan, N. The Other Version of the Story of the Storm-god's Combat with the Sea in the Light of Egyptian, Ugaritic, and Hurro-Hittite Texts. Journal of Ancient Near Eastern Religions 15 (2015), 20-51.

Bachvarova, M. R. From Hittite to Homer. The Anatolian Background of Ancient Greek Epic (Cambridge, 2016).

Barjamovic, G. A Historical Geography of Anatolia in the Old Assyrian Colony Period (Copenhagen, 2011).

Barnett, R. D. The Epic of Kumarbi and the Theogony of Hesiod. Journal of Hellenic Studies 45 (1946), 100-101.

Baumgarten, A. I. The Phoenician History of Philo of Byblos: a Commentary (Leiden, 1981).

Beckman, G. Primordial Obstetrics, in: Hethitische Literatur: Überlieferungsprozesse, Textstrukturen, Ausdrucksformen und Nachwirken: Akten des Symposiums vom 18. bis 20. Februar 2010 in Bonn, edited by M. Hutter and S. Hutter-Braunsar (Münster, 2011), 25-33.

Bernabé, A. Himno a Deméter 43-46. Adaptación de un motivo anatolio. Emerita 56 (1988), 87-93.

Bonnet, C. Typhon et Baal Saphon, in: Studia Phoenicia V. Phoenicia and the East Mediterranean in the First Millennium BC, edited by E. Lipiński (Leuven, 1987), 101-143.

Bremmer, J. N. Greek Religion and Culture, the Bible and the Ancient Near East (Leiden, 2008).

Burkert, W. Structure and History in Greek Mythology and Ritual [Sather Classical Lectures 47] (Berkeley, 1979a).

Burkert, W. Von Ullikummi zum Kaukasus: Die Felsgeburt des Unholds. Zur Kontinutät einer mündlichen Erzählung. Würzburger Jahrbuch für die Altertumswissenschaft NF 5 (1979b), 253261, reprinted in: Orientalia, edited by M. L. Gemelli Marciano (Göttingen, 2003), 87-95.

Burkert, W. The Orientalizing Revolution: Near Eastern Influence on Greek Culture in the Early Archaic Age (Cambridge, Mass.; London, 1992).

75 See Fontenrose 1959, 111 n. 36; Str. 12.8.19, 13.4.6; Nonnus Dion.13.474-8. 
Burkert, W. Kronia-Feste und ihr altorientalischer Hintergrund, in: Karnevaleske Phänomene in antiken und nachantiken Kulturn und Literaturen, edited by S. Döpp (Trier, 1993), 11-30.

Cammarosano, M. Foreign Gods in Hatti. A New Edition of CTH 510. KASKAL 12 (2015), 199-244.

Corti, C. The so-called "Theogony" or "Kingship in Heaven". The name of the Song. Studi Micenei ed Egeo-Anatolici 49 (2007), 109-121.

Corti, C. and F. Pecchioli Daddi. The Power in Heaven: Remarks on the So-Called Kumarbi Cycle, in: Organization, Representation, and Symbols of Power in the Ancient Near East, Proceedings of the 54th Rencontre Assyriologique Internationale at Würzburg, 20-25 July 2008, edited by G. Wilhelm (Winona Lake, Ind., 2012), 611-618.

Crouch, C. L. Ištar and the Motif of the Cosmological Warrior: Assurbanipal's adaptation of Enūma eliš, in: "Thus Speaks Ishtar of Arbela": Prophecy in Israel, Assyria and Egypt in the NeoAssyrian Period, edited by R. P. Gordon and H. M. Barstad (Winona Lake, Ind., 2013), 129-141.

D'Alessio, G. B. Theogony and Titanomachy, in: The Greek Epic Cycle and its Ancient Reception, edited by M. Fantuzzi and C. Tsagalis (Cambridge, 2015), 199-212.

Dijkstra, M. Ishtar Seduces the Sea-serpent. A New Join in the Epic of Hedammu (KUB 36, $56+95$ ) and its Meaning for the Battle Between Baal and Yam in Ugaritic Tradition. Ugarit-Forschungen 43 (2011), 53-83.

Dijkstra, M. El-Kunirsha in Anatolia, the Levant and Elsewhere, in Études Ougaritiques IV, edited by V. Matoian and M. al Maqdissi (Leuven; Paris; Bristol 2016), 119-138.

Dillery, J. Clio's Other Sons: Berossus and Manetho. With an Afterword on Demetrius (Ann Arbor, 2015).

Dinçol, B., Dinçol, A., Hawkins, J. D., Peker, H. and A. Öztan. Two New Inscribed Storm-God-Stelae from Arsuz (Iś kenderun): ARSUZ 1 and 2. Anatolian Studies 65 (2015), 59-77.

Durand, J.-M. Le Mythologeme du combat entre le Dieu de l'orage et la Mer en Mésopotamie. Mari annales de recherches interdisciplinaires 7 (1993), 41-61.

Faraone, C. A. Hephaistos the Magician and Near Eastern Parallels for Alcinous Watchdogs. Greek, Roman and Byzantine Studies 128 (1987), 257-280.

Faraone, C. and Teeter, E. Egyptian Maat and Hesiodic Metis. Mnemosyne 57 (2004), 177-208.

Fauth, W. Das Kasion-Gebirge und Zeus Kasios. Die antike Tradition und ihre vorderorientalischen Grundlagen. Ugarit-Forschungen 22 (1990), 105-118.

Feliu, L. The God Dagan in Bronze Age Syria (Leiden, 2003).

Fontentose, J. Python. A Study of Delphic Myth and its Origins (Berkeley; Los Angeles, 1959).

Forlanini, M. Die “Götter von Zalpa”. Hethitische Götter und Städte am Schwarzen Meer. Zeitschrift für Assyriologie und vorderasiatische Archäologie 74 (1984), 245-266.

Forrer, E. Eine Geschichte des Götterkönigtums aus dem Hatti-Reiche, in: Mélanges Franz Cumont (1936), 687-713.

Fowler, R. L. Early Greek Mythography, 2 volumes (Oxford, 2000-13).

Giusfredi, F. The Problem of the Luwian Title Tarwanis. Altorientalische Forschungen 36 (2009), 140-145.

Gruppe, 0. Typhon-Zephon. Philologus 48 (1889), 487-497.

Güterbock, H. G. Kumarbi. Mythen vom churritischen Kronos aus den hethitischen Fragmenten zusammengestellt, übersetzt und erklärt (Zurich; New York, 1946).

Haas, V. Betrachtungen zu CTH 343, ein Mythos des Hirschgottes. Altorientalische Forschungen 30 (2003), 296-303.

Haas, V. Die hethitische Literatur: Texte, Stilistik, Motive (Berlin; New York, 2006).

Haider, P. Ura - eine hethitische Handelsstadt. Münstersche Beiträge zur antiken Handelsgeschichte 14 (1995), 70-107.

Haider, P. Von Baal Zaphon zu Zeus und Typhon, in: Von Sumer bis Homer, edited by R. Rollinger (Münster, 2005), 303-337. 
Haubold, J. Greece and Mesopotamia. Dialogues in Literature (Cambridge, 2013).

Helck, W. Zur Herkunft der Erzählung des sog. 'Astartepapyrus', in: Fontes atque Pontes. Eine Festgabe für Hellmut Brunner (= Ägypten und Altes Testament ( $\ddot{A} A T)$ Bd. 5), edited by M. Görg (Wiesbaden, 1983), 215-223.

Hicks, E. L. Inscriptions from Western Cilicia. Journal of Hellenic Studies 12 (1891), 225-273.

Hoffner, H. A. Hittite Myths ${ }^{2}$ (Atlanta, 1998).

Houwink ten Cate, P. The Luwian Population Groups of Lycia and Cilicia Aspera During the Hellenistic Period (Leiden, 1961).

Huber, I. Ersatzkönige in griechischem Gewand: Die Umformung der sar puhi Rituale bei Herodot, Berossos, Agathias and den Alexander-Historikern, in: Von Sumer bis Homer, edited by R. Rollinger (Münster, 2004), 339-397.

James, P. and M. A. van der Sluijs. "Silver": A Hurrian Phaethon. Journal of Ancient Near Eastern Religions 12 (2012), 237-252.

Jasink, A. M. and M. Marino. The West Anatolian Origins of the Que Kingdom Dynasty. Studi Micenei ed Egeo-Anatolici 49 (2007), 407-426.

Koch, K. Hazzi-Safon-Kasion. Die Geschichte eines Berges und seiner Gottheiten, in: Religionsgeschichtliche Beziehungen zwischen Kleinasien, Nordsyrien und dem Alten Testament. Internationales Symposion Hamburg 17. -21. März 1990, edited by B. Janowski et al. (Freiburg; Göttingen, 1993), 171-223.

Kristiansen, K. and T. Larsson. The Rise of Bronze Age Society: Travels, Transmissions and Transformations (Cambridge, 2005).

Lane Fox, R. Travelling Heroes: Greeks and Their Myths in the Epic Age of Homer (London, 2008).

Lesky, A. Hethitische Texte und griechischer Mythos. Anzeiger der Österreichischen Akademie der Wissenschaften, Phil.-hist. Klasse, 9 (1950), 137-159 (= Gesammelte Schriften [Bern, 1966], 356-371).

Lopez-Ruiz, C. When the Gods Were Born: Greek Cosmogonies and the Near East (Cambridge, Mass., 2010).

Lopez-Ruiz, C. Ancient Mediterranean Myths: Primary Sources from Ancient Greece, Rome and the Near East (New York; Oxford, 2013).

Louden, B. lapetus and Japheth: Hesiod's Theogony, Iliad 15.187-93, and Genesis 9-10. Illinois Classical Studies 38 (2013), 1-22.

Lytle, E. The Strange Love of the Fish and the Goat: regional contexts and Rough Cilician religion in Oppian's Halieutica 4.308-73. Transactions of the American Philological Association 141:2 (2011), 333-386.

Mason, H. J. Hittite Lesbos?, in: Anatolian Interfaces: Hittites, Greeks and Their Neighbours, edited by M. Bachvarova et al. (Oxford, 2008).

Metcalf, Ch. The Gods Rich in Praise. Early Greek and Mesopotamian Religious Poetry (Oxford, 2015). Mondi, R. Greek Mythic Thought in the Light of the Near East, in: Approaches to Greek Myth, edited by L. Edmunds (Baltimore; London, 1990), 142-198.

Ogden, D. Drakōn: Dragon Myth and Serpent Cult in the Greek and Roman Worlds (Oxford, 2013).

Pardee, D. Ritual and Cult at Ugarit (Atlanta, 2002).

Parker, S. B. (ed.) Ugaritic Narrative Poetry (Atlanta, 1997).

Polvani, A. M. Temi di mitologia anatolica tra Oriente e Occidente: il dio scomparso, in: La questione delle influenze vicino-orientali sulla religione greca: stato degli studi e prospettive della ricerca. Atti del colloquio internazionale, Roma, 20-22 maggio 1999, edited by S. Ribichini et al. (Rome, 2001), 413-420.

Polvani, A. M. Relations between Rituals and Mythology in Official and Popular Hittite Religion, in: Offizielle Religion, lokale Kulte und individuelle Religiosität. Akten des religionsgeschichtlichen Symposiums "Kleinasien und angrenzende Gebiete vom Beginn des 2. bis zur Mitte des 
1. Jahrtausends v. Chr." (Bonn, 20.-22. Februar 2003), edited by M. Hutter and S. Hutter-

Braunsar (Münster, 2004), 369-376.

Polvani, A. M. The God Eltara and the Theogony. Studi Micenei ed Egeo-Anatolici 50 (2008), 617624.

Pongratz-Leisten, B. The Mythology of the Warrior God in Text, Ritual and Cultic Commentaries, and the Shaping of Marduk's Kingship. Journal of the Canadian Society for Mesopotamian Studies 7 (2014), 13-18.

Pongratz-Leisten, B. Religion and Ideology in Assyria (Boston, 2015).

Rutherford, I. The Song of the Sea (SA A-AB-BA SIR ${ }^{3}$. Thoughts on KUB 45.63, in: Akten des IV. International Kongresses für Hethitologie, Würzburg, 4.-8. Oktober 1999, edited by G. Wilhelm (Wiesbaden, 2001), 598-609.

Rutherford, I. Hesiod and the Literary Traditions of the Near East, in: Brill's Companion to Hesiod, edited by F. Montanari et al. (Leiden, 2009), 9-35.

Rutherford, I. Ea and the Beast. The Hittite Text and its Relation to the Greek Poetry, in: Hethitische Literatur: Überlieferungsprozesse, Textstrukturen, Ausdrucksformen und Nachwirken: Akten des Symposiums vom 18. bis 20. Februar 2010 in Bonn, edited by M. Hutter and S. Hutter-Braunsar (Münster, 2011), 217-226.

Rutherford, I. Sandas in Translation, in: Hittitology Today: Studies on Hittite and Neo-Hittite Anatolia in Honor of Emmanuel Laroche's 100th Birthday/L'hittitologie aujourd'hui : études sur l'Anatolie hittite et néo-hittite à l'occasion du centenaire de la naissance d'Emmanuel Laroche. IFEA, ed. by A. Mouton (Istanbul, 2017), 81-100.

Salvini, M. and I. Wegner. Die mythologischen Texte [Corpus der hurritischen Sprachdenkmäler 6] (Rome, 2004).

Smith, M. S. God in Translation: Deities in Cross-Cultural Discourse in the Biblical World (Tübingen, 2008).

Solmsen, F. The Two Near Eastern Sources of Hesiod. Hermes 117 (1989), 413-422.

Stamatopoulou, Z. Hesiod and Classical Greek Poetry. Reception and Transformation in the Fifth Century BCE (Cambridge, 2016).

Strauss Clay, J. Hesiod's Cosmos (Cambridge, 2003).

Strauss Clay, J., Gilan A. The Hittite "Song of Emergence" and the Theogony. Philologus 158: 1 (2014), 1-9.

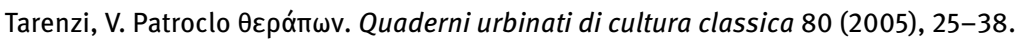

Tsagalis, C. Typhon and Eumelus' Titanomachy. Trends in Classics 5 (2013), 19-48.

van Dongen, E. The ‘Kingship in Heaven'-Theme of the Hesiodic Theogony: origin, function, composition. Greek, Roman and Byzantine Studies 51 (2011), 180-201.

van Dongen, E. The Hittite Song of Going Forth (CTH 344): a reconsideration of the narrative. Die Welt des Orients 42 (2012), 23-84.

Velde, H. te. Seth, God of Confusion: a Study of his Role in Egyptian Mythology and Religion (Leiden, 1967).

Vernant, J. P. The Myth of Prometheus in Hesiod, in: Myth and Society in Ancient Greece [tr. J. Lloyd] (Brighton, 1980), 168-185.

Versnel, H. S. Greek Myth and Ritual: the case of Kronos, in: Interpretations of Greek Mythology, edited by J. Bremmer (London, 1987), 121-152.

Watkins, C. How to Kill a Dragon (New York, 1995).

West, M. L. The East Face of Helicon (Oxford, 1997).

West, M. L. Indo-European Poetry and Myth (Oxford, 2007).

Witzel, M. The Origins of the World's Mythologies (Oxford, 2012).

Ziegler, N. Les musiciens et la musique d'après les archives de Mari (Florilegium Marianum IX) (Paris, 2007). 